\section{Evaluation of hygienic quality and labelling of fish distributed in public canteens of Northeast Italy}

\author{
Mariachiara Armani, ${ }^{1}$ Michele Civettini, ${ }^{2}$ \\ Gabriella Conedera, ${ }^{3}$ Michela Favretti, ${ }^{4}$ \\ Dorotea Lombardo, ${ }^{1}$ Rosaria Lucchini, ${ }^{5}$ \\ Sabrina Paternolli, ${ }^{5}$ Alessandra Pezzuto, ${ }^{4}$ \\ Michela Rabini, ${ }^{1}$ Giuseppe Arcangeli ${ }^{1}$ \\ ${ }^{1}$ Institute for Experimental Veterinary \\ Medicine of Venezie, Bolzano; 'Institute \\ for Experimental Veterinary Medicine of \\ Venezie, Adria (RO); ${ }^{3}$ Institute for \\ Experimental Veterinary Medicine of \\ Venezie, Pordenone; ${ }^{4}$ Institute for \\ Experimental Veterinary Medicine of \\ Venezie, San Donà di Piave (VE); \\ ${ }^{5}$ Institute for Experimental Veterinary \\ Medicine of Venezie, Trento, Italy
}

\section{Abstract}

Over the past few years, the demand for the introduction of fish products in public canteens (schools, hospitals and nursing-homes) has grown due to their good nutritional proprieties. The particular health conditions and sensitivity of some groups of consumers exposes them to greater risks of food poisoning. It is therefore important to monitor the raw materials that end up in mass catering implementing strategies of mass catering control, both with self-monitoring strategies and with regular controls performed by the competent health authorities. The purpose of this study is to assess the overall quality of seafood dealt out from public catering services located in Northeast Italy. In this paper we illustrate the results of microbiological analysis performed on 135 fish samples ( $58 \%$ of samples were raw fishes, $27 \%$ cooked fishes, $6 \%$ raw fish products, 9\% cooked fish products) and species identification performed on 102 fish samples. Additionally, 135 environmental swabs were collected to determine the effectiveness of cleaning and sanitation of food contact (cutting boards, cooking equipment and food processing surfaces) and non-contact (refrigerator wall and handle, tap lever) surfaces. Of raw seafood samples, $24 \%$ had total aerobic mesophilic bacteria count $>10^{5} \mathrm{CFU} / \mathrm{g}$ and for Enterobacteriaceae the faecal contamination was excluded since no Salmonella spp. and Escherichia coli were isolated. Just 3.8\% of raw seafood samples resulted positive for Listeria monocytogenes. The results of swab samples of cooking utensils and surfaces showed that sanitation practices should be improved.
Molecular analysis for fish species identification revealed a mislabelling for $25 \%$ of sampled fishes. The results of this survey can provide valuable information for monitoring and surveillance programmes for the control of quality of fish and fish products.

\section{Introduction}

Fish (finfish and shellfish) and fish products have become increasingly required in hospitals, nursing homes and school canteens because of the growing awareness of their high nutritional properties and potential health benefits (Mozaffarian and Rimm, 2006). However, along with the benefits, potential risks associated with consumption of contaminated seafood must be considered. Finfish and shellfish are very perishable: the high water content, non-protein nitrogen concentration and relatively high $\mathrm{pH}$ of fresh seafood make them more sensitive to microbial attack (Gram and Huss, 1996; Gram and Dalgaard, 2002). Fish, crustaceans and mollusks can acquire microorganisms from different sources: surface or tissue contamination can occur directly in the marine environment or during handling, processing and preparation of the products. Contributing factors may include storage and transportation at inappropriate temperatures, contamination by an infected food handler, or cross-contamination through contact with contaminated seafood or seawater (Iwamoto et al., 2010).

Seafood is responsible for an important proportion of food-borne illness and outbreaks worldwide. As transmission of food borne pathogens mostly occurs through the fecal-oral route, it is crucial to apply strict hygiene rules throughout the entire production process. It is therefore important to assess the hygienic conditions in the production environments through the analysis of microbial indicators of fecal contamination. In the current study aerobic mesophilic bacteria, Enterobacteriaceae and Escherichia coli were analyzed to assess the hygiene of food and food processing equipment. Furthermore, the examination of pathogens is required to assess food safety. Excluding autochthonous pathogens belonging to the genus Vibrio, other bacteria may be responsible for seafood-associated infections, like Salmonella spp. as at source contamination (i.e. in the sea), Staphylococcus aureus and Listeria monocytogenes as cross contamination (Lee and Rangdale, 2008).

Species substitution of fish must also be included in the list of potential health hazards.

Major fraud concerned high value species substituted by species with lower commercial value. Lower commercial values species could have also a lower nutritional value, moreover
Correspondence: Michela Rabini, Institute for Experimental Veterinary Medicine of Venezie, via L. Conti 4, 39100 Bolzano, Italy.

Tel: +39.0471 .633062 - Fax: +39.0471 .633580 .

E-mail: mrabini@izsvenezie.it

Key words: Public canteens; Microbiological parameters; Identification; Fish species.

Conflict of interest: the authors declare no potential conflict of interest.

Received for publication: 31 December 2015 Revision received: 14 June 2016

Accepted for publication: 14 June 2016.

This work is licensed under a Creative Commons Attribution-NonCommercial 4.0 International License (CC BY-NC 4.0).

() Copyright M. Armani et al., 2016

Licensee PAGEPress, Italy

Italian Journal of Food Safety 2016; 5:5723

doi:10.4081/ijfs.2016.5723

as observed by Filonzi et al. (2010) in many cases of substitution, fish products come from extra European areas, without the same standards of sanitary controls of farming sites, pathogens and bioaccumulation of heavy metals. Among the methods of identifying commercially imported fish species, molecular genetics is gaining increasing attention (Lockely and Bardsley, 2000) and molecular barcoding has been proposed as the favorite methodology in forensic taxonomy (Dawnay et al., 2007). For species identification, the sequence of the evidence item must be matched to a reference sequence (Altschul et al., 1997). DNA barcoding uses the mtDNA gene cytochrome c oxidase I (COI) as a barcode (Hebert et al., 2003a, 2003b).

The particular health conditions of customers of hospitals, nursing homes and school canteens expose them more than other categories to food-borne diseases. It is therefore essential to ensure the safety of raw materials, the adoption of good hygiene practices and to maintain them strictly during all stages of food preparation until distribution.

The aim of this study was to provide data on microbiological contamination of seafood and food-working surfaces in hospitals, nursing homes and school canteens and to assess the conformity of seafood species with the label information.

\section{Materials and Methods}

\section{Samples collection}

A total of 79 raw fish, 36 cooked fish and seafood, 8 raw fish products and 12 cooked fish 
products were collected from 65 public canteens located in the Northeast Italy. Selected public canteens were canteens of preschool and primary school $(\mathrm{n}=16)$, companies, universities, prisons and religious communities $(\mathrm{n}=19)$, nursing homes and facilities for disabled people $(n=26)$ and hospital canteens $(\mathrm{n}=4)$.

A sanitary monitoring program allows to assess whether every stage of the management and delivery system of catering service is kept in check: from raw material purchase to meals distribution. It was therefore decided to collect not only food samples for the assessment of safety and hygiene microbiological parameters, but also environmental samples to assess good hygiene practices adopted by the staff. Using swabbing devices, 135 surfaces and utensils have been sampled: 25 food processing surfaces, 12 fridge handles, 31 fridge inner walls, 17 knifes, 35 cutting boards and 15 tap levers. An area of $100 \mathrm{~cm}^{2}$ has been tested for each device. Samples of food non-contact surfaces have been included in the study because they may serve as a vehicle of cross contamination for food.

To assess the correspondence between the label information and the packaged product, this study focused on fish families most used in catering: Merluccidae, Pleuronectidae, Salmonidae. A total amount of 102 samples were submitted to DNA barcoding for differentiation of species.

All samples were transported in suitable thermal containers to ensure maintenance of the temperature between 0 and $4^{\circ} \mathrm{C}$.

\section{Samples analysis}

Samples were analyzed by an accredited laboratory (UNI CEI EN ISO/IEC 17025/2005; ISO, 2005). Microbiological analysis on food samples was carried out according to standard ISO methods as follow. Total aerobic mesophilic plate count was performed according to ISO 4833-1:2013 (ISO, 2013). Plates were incubated in aerobiosis at $30^{\circ} \mathrm{C}$ for 72 hours. Enterobacteriaceae were enumerated according to ISO 21528-2:2004 (ISO, 2004b). Plates were incubated in aerobiosis at $37^{\circ} \mathrm{C}$ for 24 hours. Escherichia coli glucuronidase positive at $44^{\circ} \mathrm{C}$ were tested following ISO 166492:2001 (ISO, 2001) incubating plates in aerobiosis at $44^{\circ} \mathrm{C}$ for 24 hours. Coagulase positive staphylococci count was performed according to ISO 6888-2:1999 Amd 12003 (ISO, 2003). Plates were incubated in aerobiosis at $37^{\circ} \mathrm{C}$ for $48 \mathrm{~h}$.

Presence of Salmonella spp. was tested according to ISO 6579:2002/Cor 1:2004 (E) and Listeria monocytogenes to ISO 11290-1:2005 (ISO, 2002, 2005).

The sampling procedure for environmental swabs followed standard ISO 18593:2004 (IS0, 2004a). Succeeding analysis for total mesophilic aerobic count (ISO 4833-1:2013; ISO, 2013), Enterobacteriaceae (ISO 215282:2004; ISO, 2004b) and Listeria monocytogenes (ISO 11290-1:2005; ISO, 2005) were carried out accordingly to already cited standard ISO. For fish species identification, DNA from all samples was recovered using the Qiaamp ${ }^{\circledR}$ DNA Minikit (Qiagen, Venlo, The Netherlands) commercial kit.
DNA was amplified using COI universal primers (Coifish F1: 5' TCAACYAATCAYAAAGATATYGGCAC3' and CoifishR1: 5' ACTTCYGGGTGRCCRAARAATCA3'). PCR products were sequenced and all sequences were analyzed using Ittiobase (http://90.147.123.23/ ittiobase/), GenBank (http://www.ncbi.nlm.nih. gov/genbank/) and BOLD Identification System (http://www.boldsystems.org) databases for species identification.

\section{Results}

\section{Food samples}

The sampling, carried out in different facilities, allowed the identification of the most commonly used fish genera by catering services. Among raw fish, the most represented genera were Pleuronectiformes (30\% of samples), Gadiformes (28\%), Perciformes (10\%), Salmoniformes (9\%), Carcharhiniformes (7\%) and Sepiida (6\%). Among cooked fish Pleuronectiformes were the most represented too (44\%), followed by Gadiformes (19\%), Perciformes (14\%) and Salmoniformes (14\%).

The microbiological analysis on raw and cooked fish, raw and cooked fish products are presented in Table 1.

Regarding the distribution of microbial population $31 \%$ of raw fish and seafood presented an aerobic mesophilic bacteria count in the range of $10^{3}-10^{4} \mathrm{CFU} / \mathrm{g}, 34 \%$ in the range of $10^{4}-10^{5} \mathrm{CFU} / \mathrm{g}$, and $24 \%$ higher than $10^{5} \mathrm{CFU} / \mathrm{g}$. Contamination with Enterobacteriaceae

Table 1. Results of aerobic mesophilic colony count, coagulase positive staphylococci, Enterobacteriaceae and Escherichia coli $\beta$ glucuronidase positive in raw and cooked fish, raw and cooked fish products.

\begin{tabular}{|c|c|c|c|c|c|c|c|}
\hline Analysis in different sample types & $\mathbf{N}$ & $\begin{array}{c}<10 \\
(\mathrm{CFU} / \mathrm{g})\end{array}$ & $\begin{array}{c}10 \text { to }<10^{2} \\
(\mathrm{CFU} / \mathrm{g})\end{array}$ & $\begin{array}{c}10^{2} \text { to }<10^{3} \\
(\mathrm{CFU} / \mathrm{g})\end{array}$ & $\begin{array}{c}10^{3} \text { to }<10^{4} \\
(\mathrm{CFU} / \mathrm{g})\end{array}$ & $\begin{array}{c}10^{4} \text { to }<10^{5} \\
(\mathrm{CFU} / \mathrm{g})\end{array}$ & $\begin{array}{c}>10^{5} \\
(\mathrm{CFU} / \mathrm{g})\end{array}$ \\
\hline Raw fish & & & & & & & \\
\hline $\begin{array}{l}\text { Aerobic mesophilic colony count } \\
\text { Coagulase positive staphylococci } \\
\text { Enterobacteriaceae } \\
\text { Escherichia coli } \beta \text { glucuronidase positive }\end{array}$ & $\begin{array}{l}79 \\
77 \\
77 \\
78\end{array}$ & $\begin{array}{c}1 \\
77 \\
74 \\
78\end{array}$ & $\begin{array}{c}08 \\
00 \\
01 \\
0\end{array}$ & $\begin{array}{c}26 \\
0 \\
1 \\
0\end{array}$ & $\begin{array}{c}26 \\
0 \\
0 \\
0\end{array}$ & $\begin{array}{c}18 \\
0 \\
1 \\
0\end{array}$ & \\
\hline $\begin{array}{l}\text { Cooked fish } \\
\text { Aerobic mesophilic colony count } \\
\text { Coagulase positive staphylococci } \\
\text { Enterobacteriaceae } \\
\text { Escherichia coli } \beta \text { glucuronidase positive }\end{array}$ & $\begin{array}{l}36 \\
36 \\
35 \\
30\end{array}$ & $\begin{array}{l}19 \\
36 \\
33 \\
30\end{array}$ & $\begin{array}{c}10 \\
00 \\
11 \\
00\end{array}$ & $\begin{array}{l}6 \\
0 \\
0 \\
0\end{array}$ & $\begin{array}{l}1 \\
0 \\
0 \\
0\end{array}$ & $\begin{array}{l}0 \\
0 \\
0 \\
0\end{array}$ & 0 \\
\hline $\begin{array}{l}\text { Raw fish products } \\
\text { Aerobic mesophilic colony count } \\
\text { Coagulase positive staphylococci } \\
\text { Enterobacteriaceae } \\
\text { Escherichia coli } \beta \text { glucuronidase positive }\end{array}$ & $\begin{array}{l}8 \\
8 \\
8 \\
8\end{array}$ & $\begin{array}{l}0 \\
8 \\
6 \\
8\end{array}$ & $\begin{array}{l}01 \\
00 \\
01 \\
00\end{array}$ & $\begin{array}{l}2 \\
0 \\
1 \\
0\end{array}$ & $\begin{array}{l}5 \\
0 \\
0 \\
0\end{array}$ & $\begin{array}{l}0 \\
0 \\
0 \\
0\end{array}$ & \\
\hline $\begin{array}{l}\text { Cooked fish products } \\
\text { Aerobic mesophilic colony count } \\
\text { Coagulase positive staphylococci } \\
\text { Enterobacteriaceae } \\
\text { Escherichia coli } \beta \text { glucuronidase positive }\end{array}$ & $\begin{array}{c}11 \\
10 \\
10 \\
9\end{array}$ & $\begin{array}{l}3 \\
0 \\
9 \\
9\end{array}$ & $\begin{array}{l}43 \\
00 \\
10 \\
00\end{array}$ & $\begin{array}{l}0 \\
0 \\
0 \\
0\end{array}$ & $\begin{array}{l}0 \\
0 \\
0 \\
0\end{array}$ & $\begin{array}{l}1 \\
0 \\
0 \\
0\end{array}$ & \\
\hline
\end{tabular}

$\mathrm{N}$, number of samples analysed; $\mathrm{CFU}$, colony forming unit. 
occurred only in 3 cases and the values of the three samples were: $10^{2}$ to $10^{3} \mathrm{CFU} / \mathrm{g}, 10^{3}$ to $10^{4}$ $\mathrm{CFU} / \mathrm{g}$ and $>10^{5} \mathrm{CFU} / \mathrm{g}$. In all the three cases the samples belonged to Pleuronectiformes: 2 plaices (Pleuronectes platessa) sampled in two school canteens, and a common dab taken from a nursing home canteen. Enterobacteriaceae in the remaining samples were always under the detection limit $(<10$ CFU/g). Concerning cooked fish, 55\% of the samples showed an aerobic mesophilic bacteria count under the detection limit $(<10$ $\mathrm{CFU} / \mathrm{g}$ ). In the majority of samples analyzed (94\%) Enterobacteriaceae were below the sensitivity method threshold ( $<10 \mathrm{CFU} / \mathrm{g}$ ), just one sample, a grouper (Epinephelus marginatus) fillet, contained $140 \quad \mathrm{CFU} / \mathrm{g}$ Enterobacteriaceae. The grouper was sampled in collective canteen. In all samples of raw fish products analyzed, the aerobic colony count ranged from $10^{2}$ to $<10^{5} \mathrm{CFU} / \mathrm{g}$ and Enterobacteriaceae were always $<10 \mathrm{CFU} / \mathrm{g}$ except for a cod stick sample, which contained $4700 \mathrm{CFU} / \mathrm{g}$ Enterobacteriaceae.

Concluding with cooked fish products, in $90 \%$ of the samples analyzed the aerobic colony count was below $10^{3} \mathrm{CFU} / \mathrm{g}$ and Enterobacteriaceae were under the detection limit (<10 CFU/g).

None of the four types of samples (raw and cooked fish, raw and cooked fish products) tested for coagulase positive Staphylococci and E. coli were above the detection limit (10 $\mathrm{CFU} / \mathrm{g}$ ). No Salmonella spp. has been found in any samples, whereas three samples were positive for Listeria monocytogenes: a frozen squid (Dosidiscus gigas), frozen fillets of blue shark (Prionace glauca) and halibut (Hippoglossus hippoglossus). Even though the isolation of Listeria monocytogenes has been verified, its concentration was always $<10 \mathrm{CFU} / \mathrm{g}$.

\section{Environmental swabs}

Total counts of aerobic mesophilic bacteria are presented in Figure 1. In 50\% of samples the total count of aerobic mesophilic bacteria was in the range of $1-10 \mathrm{CFU} / \mathrm{cm}^{2}, 25 \%$ in the range of $10-10^{2} \mathrm{CFU} / \mathrm{cm}^{2}$ and the remaining $25 \%$ had counts $>10^{2} \mathrm{CFU} / \mathrm{cm}^{2}$. Only two samples had a total count of aerobic mesophilic bacteria $>10^{5} \mathrm{CFU} / \mathrm{cm}^{2}$; both were samples of food processing surfaces of school canteens. Enterobacteriaceae were always below the sensitivity method threshold $\left(<1 \mathrm{CFU} / \mathrm{cm}^{2}\right)$ and no Listeria monocytogenes was found.

\section{Fish species identification}

Fish sampled for species identification belonged mostly to genera Gadiformes (31\%), Pleuronectiformes (20\%), Perciformes (11\%), Salmoniformes (10\%), Squaliformes (5\%) and Sepiida (5\%) (Figure 2). Out of 102 samples, 98 (96.1\%) revealed valuable sequence results, while 4 samples (3.9\%) did not give valid results due to poor DNA quality, and were therefore discarded. Results of molecular analysis for differentiation of species are reported in Table 2.

\section{Discussion}

The results of this study constitute an indicator of the overall quality of seafood and fish products served by public catering services.

Fish is one of the food categories with the shortest shelf life, and its quality is influenced by many factors as the source, cooling methods, processing and storage conditions (Stratev et al., 2015).

The International Commission on Microbiological Specifications for Foods sets the limit for total aerobic plate counts in fresh and frozen fish at $10^{7} \mathrm{CFU} / \mathrm{g}$ and as stated by Broekaert et al. (2011), loads of $10^{7}-10^{8} \mathrm{CFU} / \mathrm{g}$ make spoilage organoleptically detectable. In this study, $24 \%$ of raw fish samples had total aerobic mesophilic bacteria count above $10^{5}$ CFU/g, but only two raw plaices (Pleuronectes platessa), sampled in two different canteens of nursery schools, had an aerobic mesophilic bacteria load of $10^{6}$ to $<10^{7}$ and $>10^{7} \mathrm{CFU} / \mathrm{g}$. These two samples had also Enterobacteriaceae loads respectively of $2.1 \times 10^{3} \mathrm{CFU} / \mathrm{g}$ and $2.5 \times 10^{5} \mathrm{CFU} / \mathrm{g}$. From these two samples, other samples that showed an Enterobacteriaceae contamination were a raw common dab (Limanda limanda) fillet $\left(3.6 \times 10^{2} \mathrm{CFU} / \mathrm{g}\right)$, a raw cod stik sample $\left(4.7 \times 10^{3} \mathrm{CFU} / \mathrm{g}\right)$ and a cooked grouper (Epinephelus marginatus) fillet $\left(1.4 \times 10^{2}\right.$ CFU/g). The Enterobacteriaceae count is considered as a fish quality index indicator because it is related to storage on ice, washing, evisceration (Zambuchini et al., 2008) and handling of seafood. The Enterobacteriaceae contamination was found only in a small amount of samples in this investigation, but the concentration was unacceptable if compared to the limit of $10^{2} \mathrm{CFU} / \mathrm{g}$ established by Popovic et al. (2010) for fresh and frozen fish. No E.coli and Salmonella spp. were isolated, allowing to exclude a contamination by Enterobacteriaceae of fecal origin. In Italy, however, a two-year survey demonstrated a rate of Salmonella spp. in seafood of $0.5 \%$ (Busani et al., 2005).

Pathogens could be transmitted to fish in water (i.e. Salmonella spp.) or during processing under bad hygienic conditions (Uddin et al., 2013), as Listeria monocytogenes. Contamination of fish with Listeria monocytogenes in the early stages of the production chain could follow the product throughout the production process (Svanevik et al., 2015).
A

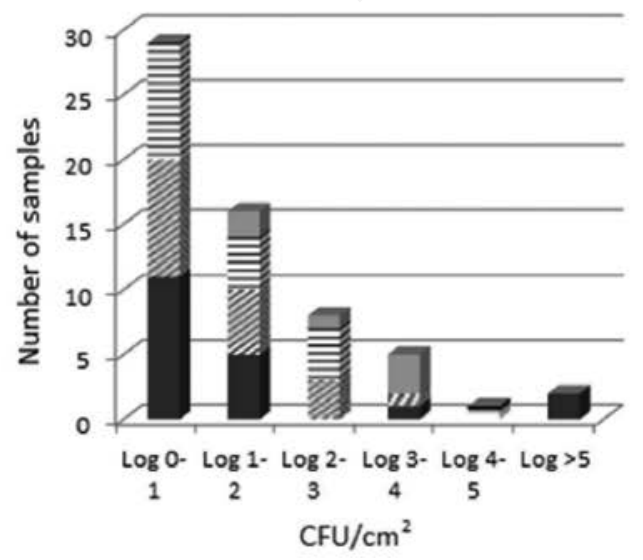

B

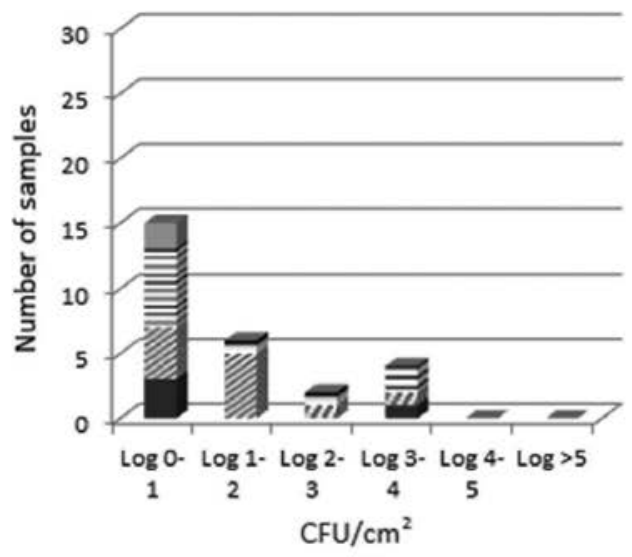

n HOSPITAL CANTEENS

$=$ HEALTH CARE CANTEENS

* CORPORATE CANTEENS

- SCHOOL CANTEENS

Figure 1. Total counts of aerobic mesophilic bacteria ( $\mathrm{Log}$ colony forming unit/ $\mathrm{cm}^{2}$ ) on: A) food contact surfaces (processing surfaces, chopping boards, knives) and B) food non-contact surfaces (fridge inner wall, fridge handles, tap lever). 
Once the pathogen is established in a processing environment, it can be a long-term source of contamination because of its ability to form biofilms on processing surfaces. Additionally, Listeria monocytogenes is known to tolerate low temperatures, including freezing temperature, which can reduce its chance of being eliminated from the product (Rocourt et al., 2000). Listeria monocytogenes was detected only in $3.8 \%$ of raw seafood samples, a considerably lower percentage in comparison with the $6.5 \%$ found by Busani et al. (2005). Furthermore, the quantitative analysis of these samples attested that the concentration of Listeria monocytogenes was always $<10$ $\mathrm{CFU} / \mathrm{g}$. Even though the detected concentration of Listeria monocytogenes was below the $100 \mathrm{CFU} / \mathrm{g}$, accepted by the International Commission on Microbiological Specification for Foods, it is of major concern because these samples were collected from canteens mostly dedicated to a population particularly vulnerable to food-borne illness.

Food contact surfaces are a major concern for food service facilities in controlling the spread of food-borne pathogens (Cosby et al., 2008), thus the evaluation of their bacteriological quality has been included in this investi- gation. Henroid et al. (2004) suggested a standard of less than $1.3 \log _{10} \mathrm{CFU} / \mathrm{cm}^{2}$ as acceptable level for aerobic mesophilic bacteria count and for Enterobacteriaceae less than $1.0 \log _{10}$ $\mathrm{CFU} / \mathrm{cm}^{2}$. Compared to this standard just $14 \%$ of surfaces samples were acceptable for aerobic mesophilic bacteria count, whereas the standards for Enterobacteriaceae count was met for all samples. The high percentage of unacceptable samples for aerobic mesophilic bacteria plate count indicates either inadequate sanitation or recontamination, but the satisfactory levels of Enterobacteriaceae reassure that human enteric pathogens have been

Table 2. Data of polymerase chain reaction species identification.

\begin{tabular}{|c|c|c|c|c|c|}
\hline Genus & Families & $\begin{array}{l}\text { PCR species } \\
\text { identification }\end{array}$ & $\begin{array}{l}\text { Compliant } \\
\text { samples (n) }\end{array}$ & $\begin{array}{l}\text { Not compliant } \\
\text { samples (n) }\end{array}$ & $\begin{array}{l}\text { Label denomination } \\
\text { for not-complying samples }\end{array}$ \\
\hline Gadiformes & $\begin{array}{l}\text { Gadidae } \\
\text { Merlucciidae }\end{array}$ & $\begin{array}{l}\text { Theragra chalcogramma } \\
\text { Gadus morhua } \\
\text { Merluccius productus } \\
\text { Merluccius capensis } \\
\text { Merluccius paradoxus } \\
\text { Macruronus novazelandiae } \\
\text { Merluccius hubbsi } \\
\text { Merluccius gayi } \\
\text { Merluccius merluccius }\end{array}$ & $\begin{array}{l}4 \\
1 \\
0 \\
3 \\
0 \\
3 \\
6 \\
2 \\
0\end{array}$ & $\begin{array}{l}5 \\
1 \\
1 \\
1 \\
2 \\
1 \\
1 \\
0 \\
1\end{array}$ & $\begin{array}{c}3 \text { generic codfishes; } 1 \text { generic plaice; } 1 \text { generic crab } \\
1 \text { generic codfish } \\
1 \text { generic codfish } \\
1 \text { generic codfish } \\
2 \text { generic South-African codfish } \\
1 \text { generic plaice } \\
1 \text { generic codfish } \\
1 \text { generic South-African codfish }\end{array}$ \\
\hline Pleuronectiformes & Pleuronectidae & $\begin{array}{l}\text { Pleuronectes platessa } \\
\text { Reinhardtius hippoglossoides } \\
\text { Lepidopsetta polyxystra }\end{array}$ & $\begin{array}{l}10 \\
5 \\
0\end{array}$ & $\begin{array}{l}0 \\
5 \\
1\end{array}$ & $\begin{array}{c}4 \text { generic halibut, } 1 \text { generic plaice } \\
1 \text { generic limanda }\end{array}$ \\
\hline Perciformes & $\begin{array}{l}\text { Serranidae } \\
\text { Centropomidae } \\
\text { Cichlidae } \\
\text { Moronidae } \\
\text { Scombridae } \\
\text { Sparidae } \\
\text { Xiphiidae }\end{array}$ & $\begin{array}{l}\text { Acanthistius brasilianus } \\
\text { Epinephelus sp. } \\
\text { Lates niloticus } \\
\text { Oreocromis niloticus } \\
\text { Dicentrarchus labrax } \\
\text { Thunnus sp. } \\
\text { Scomber scombrus } \\
\text { Sparus aurata } \\
\text { Xiphias gladius }\end{array}$ & $\begin{array}{l}0 \\
0 \\
0 \\
1 \\
1 \\
1 \\
2 \\
1 \\
2\end{array}$ & $\begin{array}{l}1 \\
1 \\
1 \\
0 \\
0 \\
0 \\
0 \\
0 \\
0\end{array}$ & $\begin{array}{l}1 \text { generic grouper } \\
1 \text { generic Atlantic grouper } \\
1 \text { Greenlandic halibut }\end{array}$ \\
\hline Salmoniformes & Salmonidae & $\begin{array}{l}\text { Oncorhynchus mykiss } \\
\text { Oncorhynchus keta } \\
\text { Salmo salar } \\
\text { Salvelinus fontinalis }\end{array}$ & $\begin{array}{l}6 \\
1 \\
1 \\
1\end{array}$ & $\begin{array}{l}1 \\
0 \\
0 \\
0\end{array}$ & 1 keta salmon \\
\hline Scaridae Sepiida & $\begin{array}{l}\text { Scarus } \\
\text { Sepiidae }\end{array}$ & $\begin{array}{l}\text { Scarus sp. } \\
\text { Sepia officinalis } \\
\text { Sepiella } s p .\end{array}$ & $\begin{array}{l}0 \\
3 \\
1\end{array}$ & $\begin{array}{l}1 \\
0 \\
1\end{array}$ & $\begin{array}{l}1 \text { generic grouper } \\
1 \text { Sepia pharaonis }\end{array}$ \\
\hline Squaliformes & Prionace & Prionace glauca & 5 & 0 & \\
\hline Clupeiformes & Clupeidae & Sardina pilchardus & 3 & 0 & \\
\hline Mugiliformes & Mugilidae & Liza ramada & 2 & 0 & \\
\hline Siluriformes & Pangasiidae & Pangasius hypophtalmus & 2 & 0 & \\
\hline Scorpaeniformes & Triglidae & Chelidonichtys cuculus & 1 & 0 & \\
\hline Zeiformes & Zeidae & Zeus faber & 1 & 0 & \\
\hline Mytiloida & Mytilidae & Mytilus sp. & 1 & 0 & \\
\hline Atheriniformes & Atherinidae & Atherina boyeri & 1 & 0 & \\
\hline Lamniformes & Lamnidae & Isurus oxyrhincus & 1 & 0 & \\
\hline Veneroida & Veneridae & Paphia undulata & 1 & 0 & \\
\hline
\end{tabular}

$\mathrm{PCR}$, polymerase chain reaction. 


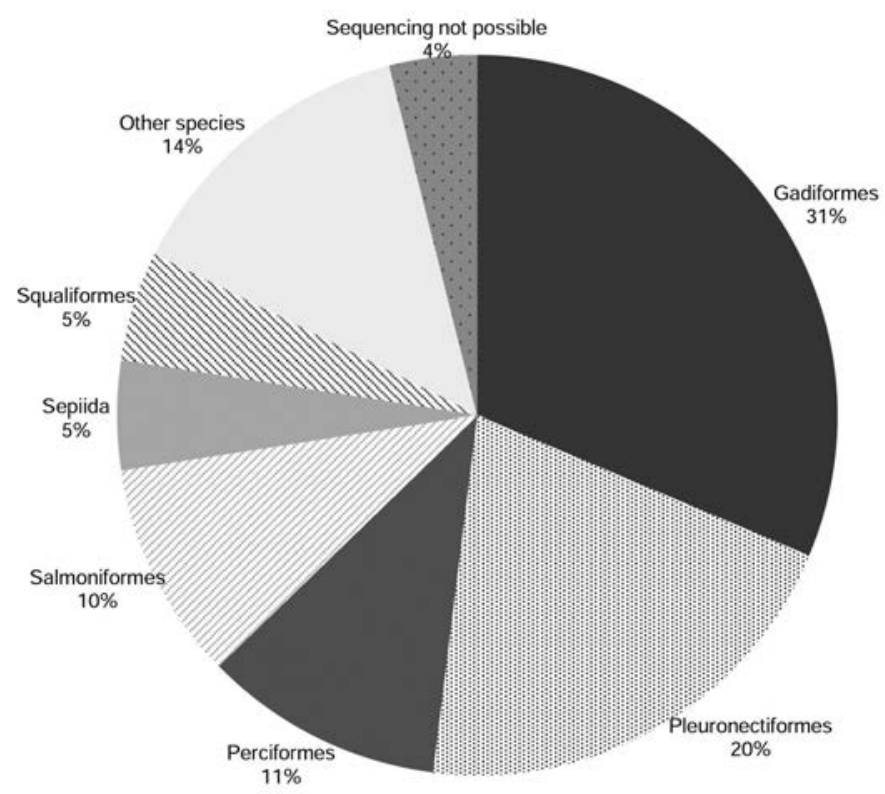

Other species: Squaliformes, Clupeiformes, Mugiliformes, Siluriformes.

Figure 2. Sample size for species identification.

controlled. Concerning pathogens, no Listeria monocytogenes have been found on food contact and non-contact surfaces indicating that no cross contamination occurred even if three samples tested positive for Listeria monocytogenes.

In food catering services, especially if dedicated to peoples at high health risk, it is essential to maintain high hygiene standards starting from raw materials. It's therefore necessary to ensure the authenticity and the origin of seafood, particularly for those products which are visually not recognizable after processing and freezing. The results of this investigation show that a considerable portion (75\%) of analyzed samples revealed a correct species declaration, and most cases of mislabelling were example of species with a low market value sold as others more expansive. Major frauds concerned codfish and groupers; one labelled grouper was identified as Scarus spp. at molecular level, a species with a very low commercial value with respect to grouper. In accordance to our findings, Filonzi et al. (2010) reported the Mediterranean grouper among the major substituted species.

\section{Conclusions}

The results of the microbiological raw fish and fish products, served by mass catering, can be defined as quite satisfactory, given that the majority of samples complied with the refer- ence standards. Anyway the unsatisfactory results of aerobic mesophilic bacteria on environmental samples indicate inadequate sanitation procedures or a recontamination.

The results of species identification reveal the need to improve controls on raw fish, in order to avoid frauds which can damage the consumers not only economically but also from a nutritional perspective. Thus, food business operators have to maintain a high level of attention, especially when providing meals to vulnerable populations

The results of this survey can provide valuable information for the design of monitoring and surveillance programs for the control of quality of seafood and fish products.

\section{References}

Altschul S, Madden T, Schäffer A, Zhang J, Zhang Z, Miller W, Lipman DJ, 1997. Gapped BLAST and PSI-BLAST: a new generation of protein database search programs. Nucleic Acids Res 25:3389-402.

Broekaert K, Heyndrickx M, Herman L, Devlighere F, Vlaemynk G, 2011. Seafood quality analysis: molecular identification of dominant microbiota after ice storage on several general growth media. Food Microbiol 18:1162-9.

Busani L, Cigliano A, Taioli E, Caliguiuri V, Chiavacci L, Di Bella C, Battisti A, Duranti A, Gianfranceschi M, Nardella MC, Ricci A,
Rolesu S, Tamba M, Marabelli R, Caprioli A, 2005. Prevalence of Salmonella enterica and Listeria monocytogenes contamination in foods of animal origin in Italy. $\mathbf{J}$ Food Protect 68:1729-33.

Cosby CM, Costello CA, Morris WC, Haughton B, Devereaux MJ, Harte F, Davidson PM, 2008. Microbiological analysis of food contact surfaces in child care centers. Appl Environ Microb 74:6918-22.

Dawnay N, Ogden R, McEwing R, Carvalho GR, Thorpe RS, 2007. Validation of the barcoding gene COI for use in forensic genetic species identification. Forensic Sci Int 173:1-6.

Filonzi L, Chiesa S, Vaghi M, Nonnis Marzano F, 2010. Molecular barcoding reveals mislabelling of commercial fish products in Italy. Food Res Int 43:1383-8.

Gram L and Huss HH, 1996. Microbiological spoilage of fish and fish products. Int $\mathrm{J}$ Food Microbiol 33:121-37.

Gram L, Dalgaard P, 2002. Fish spoilage bacteria - problems and solutions. Curr Opin Biotech 13:262-6.

Hebert PDN, Cywinska A, Ball SL, de Waard JR, 2003a. Biological identifications through DNA barcodes. P Roy Soc Lond B Bio 270:313-1.

Hebert PDN, Ratnasingham S, deWaard JR, 2003b. Barcoding animal life: cytochrome c oxidase subunit 1 divergences among closely related species. P Roy Soc Lond B Bio 270:96-9.

Henroid DH, Mendonca AF, Sneed J, 2004. Microbiological evaluation of food contact surfaces in Iowa schools. Food Prot Trends 24:682-5.

ISO, 2001. Microbiology of food and animals feeding stuffs. Horizontal method for the enumeration of -glucuronidase - positive Escherichia coli - Part 2: Colony-count technique at $44^{\circ} \mathrm{C}$ using 5-bromo-4-chloro3-indolyl - D- glucuronide. ISO Norm 16649-2: 2001. International Standardization Organization ed., Geneva, Switzerland.

ISO, 2002. Microbiology of food and animal feeding stuffs - Horizontal method for the detection Salmonella spp. ISO Norm 6579: 2002/Cor 1:2004. International Standardization Organization ed., Geneva, Switzerland.

ISO, 2003. Microbiology of food and animals feeding stuffs. Horizontal method for the enumeration of coagulase-positive staphylococci (Staphylococcus aureus and other species). Part 2: Technique using rabbit plasma fibrinogen agar medium. Amendment 1: Inclusion of precision data. ISO Norm 6888-2: 2003. International Standardization Organization ed., Geneva, Switzerland.

ISO, 2004a. Microbiology of food and animals 
feeding stuffs-Horizontal methods for sampling techniques from surfaces using contact plates and swabs. ISO Norm 18593: 2004. International Standardization Organization ed., Geneva, Switzerland.

ISO, 2004b. Microbiology of food and animals feeding stuffs - Horizontal methods for the detection and enumeration of Enterobacteriaceae. Part 2 Colony - count method. ISO 21528-2: 2004. International Standardization Organization ed., Geneva, Switzerland.

ISO, 2005. Microbiology of food and animal feeding stuffs. Horizontal method for the detection and enumeration of Listeria monocytogenes. ISO Norm 11290-1: 2005. International Standardization Organization ed., Geneva, Switzerland.

ISO, 2013. Microbiology of food and animals feeding stuffs - UN EN ISO 4833-1 Horizontal method for enumeration of microorganisms. Part 1: Colony count at 30 degrees $\mathrm{C}$ by the pour plate technique. ISO Norm 4833-1: 2013. International
Standardization Organization ed., Geneva, Switzerland.

Iwamoto M, Ayers T, Mahon EB, Swerdlow D, 2010. Epidemiology of seafood-associated infections in the united states. Clin Microbiol Rev 23:399-411.

Lee RJ, Rangdale RE, 2008. Bacterial pathogens in seafood. In: Torger Borresen eds. Improving seafood products for the consumer. Woodhead Publishing, Cambridge, UK, pp 1-70.

Lockely AK, Bardsley RG, 2000. DNA-based methods for food authentication. Trends Food Sci Tech 11 67-70.

Mozaffarian D, Rimm EB, 2006. Fish intake, contaminants, and human health: evaluating the risks and the benefits. J Am Med Assoc 296:1885-9.

Popovic NT, Benussi Skukan A, Dzidara P, CozRakovac R, Strunjak-Perovic I, Kozacinski L, Jadan M, Brlek-Gorski D, 2010. Microbiological quality of marketed fresh and frozen seafood caught off the Adriatic coast of Croatia. Vet Med-Czech 55:233-41.
Rocourt J, Jaquet C, Reilly A, 2000. Epidemiology of human listeriosis and seafoods. Int J Food Microbiol 62:197-9.

Stratev D, Vashin I, Daskalov H, 2015. Microbiological status of fish products on retail markets in the republic of Bulgaria. Int Food Res J 22:64-9.

Svanevik CS, Roiha IS, Levsen A, Lunestad BT, 2015. Microbiological assessment along the fish production chain of the Norwegian pelagic fisheries sector. Results from a spot sampling programme. Food Microbiol 51:144-3.

Uddin G, Larsen MH, Guardabassi L, Dalsgaard A, 2013. Bacterial flora and antimicrobial resistence in raw frozen cultured seafood imported to Denmark. J Food Protect 76:490-9.

Zambuchini B, Fiorini D, Verdenelli MC, Orpianesi C, Ballini R, 2008. Inhibition of microbiological activity during sole (Solea solea L.) chilled storage by applying ellagic and ascorbic acids. Lwt-Food Sci Technol 41:1733-8. 